\title{
Why did the Rule of Law Revive?
}

\author{
Ronald Janse ${ }^{1}$
}

Published online: 5 November 2019

(c) The Author(s) 2019

\section{The Rule of Law is Everywhere}

"One cannot get through a foreign policy debate these days without someone proposing the rule of law as a solution to the world's troubles". Thus wrote Thomas Carothers $(1998,95)$ in "The rule of law revival", published in Foreign Affairs in March/April 1998. In this article, the American publicist looked back on the first decade after the end of the Cold War. During this period international organizations, states and private funds had started to invest mind-boggling sums of money and energy in building, promoting and strengthening the rule of law in countries across the world. They still do.

In Europe the rule of law revival centred on post-communist countries. In 1993 the European Council "agreed that the associated countries in Central and Eastern Europe that so desire shall become members of the European Union", provided that they met the so-called Copenhagen political criteria, which required countries to achieve the "stability of institutions guaranteeing democracy, the rule of law, human rights and respect for and protection of minorities". After the accession of ten countries in 2004 and 2007 the EU shifted its attention to countries in the Western Balkans. This slow and cumbersome process is still ongoing. Meanwhile, EU institutions have their hands full in countering rule of law decay in Hungary and Poland.

The World Bank, the United Nations Development Programme, the International Development Law Organization and many other organizations in development cooperation discovered the rule of law at the end of the 1980s. By the mid 2000s, the significance of the rule of law for development had become accepted wisdom. In 2008 a major UNDP report called Making the Law Work for Everyone, spearheaded by Madeleine Albright and the development economist Hernando de Soto, argued that "four billion people around the world are robbed of the chance to better their lives and climb out of poverty, because they are excluded from the rule of law". In his speech Fragile states: securing development, delivered in the same year, the then World Bank President Robert Zoellick $(2008,68)$ said: "the most important fundamental prerequisite for sustainable development is an effective rule of law".

Ronald Janse

ronald.janse@ou.nl

1 Open University, Heerlen, The Netherlands 
Post-conflict peacebuilding in such places as Kosovo, East Timor and Bosnia-Herzegovina was another domain where the rule of law came to occupy a central role. After violent conflicts a relapse to violence occurs within 5 years in $50 \%$ of all cases. The rule of law can contribute to breaking this vicious cycle, or so it was thought. As the late Kofi Annan wrote in The Rule of Law and Transitional Justice in Conflict and Post-conflict Societies: "Our experience in the past decade has demonstrated clearly that the consolidation of peace in the immediate post-conflict period, as well as the maintenance of peace in the long term, cannot be achieved unless the population is confident that redress for grievances can be obtained through legitimate structures for the peaceful settlement of disputes and the fair administration of justice. At the same time, the heightened vulnerability of minorities, women, children, prisoners and detainees, displaced persons, refugees and others, which is evident in all conflict and post-conflict situations, brings an element of urgency to the imperative of restoration of the rule of law" (S/2004/616, para. 2).

9/11 marked the beginning of rule of law promotion on steroids. In 2001 NATO attacked Afghanistan to root out Al Qaeda and decimate the Taliban; 2 years later Iraq was invaded and Western armies found themselves in the midst of sectarian violence. The military doctrine of counter-insurgency, at the time, held that these battles could not be won by military force only. As General David H. Petraeus and Lieutenant-General James F. Amos wrote in their foreword to Army Field Manual 3-24: Counterinsurgency: "Soldiers and Marines are expected to be nation builders as well as warriors. They must be prepared to help reestablish institutions and local security forces and assist in rebuilding infrastructure and basic services. They must be able to facilitate establishing local governance and the rule of law". ${ }^{2}$

A year after 9/11, in 2002, the International Criminal Court started its work in The Hague. The Court was to investigate and prosecute individuals who participate in genocide, crimes against humanity, and war crimes. It was to be a court of last resort which would complement other courts that had jurisdiction over the alleged crimes. It was supposed to focus on high-profile cases; the bulk would have to be dealt with by courts in countries where crimes had been perpetrated. This presupposed that these domestic courts were "genuinely able and willing" to investigate and potentially prosecute the case. And that, in turn, required serious reforms and investments in the capacity of judicial systems, for these were often weak in countries where the gravest crimes were being committed.

The rule of law also became much talked about on the international plane. In 2006 the UN General Assembly adopted a resolution on the rule of law at the national and international levels. Since then the international rule of law is a standard item on the agenda of the Sixth Committee of the UNGA, which deals with legal affairs. In 2012 the Heads of State and Government came together in New York to adopt their first ever resolution on the rule of law.

Accompanying the explosive growth of interest in, and funding for, the rule of law, a new world emerged of NGOs, national and international, big and small, which specialized in designing and implementing rule of law projects, assessing the impact

1 United States Army (2006), foreword. 
of such programmes, measuring the rule of law around the world, and advising governments on rule of law policies. The World Justice Project and its Rule of Law Index, the Open Society Justice Initiative, Creative Contracts, HiiL, CrimeSync and Barefoot Lawyer are just the tip of the iceberg of the many rule of law organizations which have been multiplying over the past few decades.

Academic interest in the rule of law also grew significantly, not just by legal scholars, but by political scientists, economists, anthropologists and sociologists as well, witnessed by an avalanche of research programmes, monographs, edited volumes and articles since the early 1990s. And of course the first international journal on the rule of law, this journal, was launched in 2009, following a suggestion by Thomas Carothers in a conversation with HiiL's director Sam Muller.

\section{Global Phenomenon, Global Causes?}

Why has the rule of law become a global ideal and endeavour? Whereas the rise of human rights has become the object of an extensive and lively historiography, so much so that a few years back it was already time for the revisionist iconoclasm of Samuel Moyn's The Last Utopia, next to nothing has been written about the origins of the rule of law revival. One of the few exceptions is a wonderful chapter by Martin Krygier called The Rule of Law after the Short Twentieth Century; Launching a Global Career. ${ }^{2}$ As Nick Cheesman and I have argued in the introduction to this Special Issue of the Hague Journal on the Rule of Law, Krygier can be regarded as a theorist of the rule of law revival, so perhaps it was to be expected that he would give some thought to analysing its origins as well.

Inspired by Moyn, and extending the main argument of The Last Utopia to his own field of expertise, Krygier insists that the international omnipresence of the rule of law is a recent thing, notwithstanding some precedents of rule of law promotion in the past, including the Law and Development movement of the late 1960s. Krygier argues that the launching of its global career in the late 1980s had three main causes. ${ }^{3}$ Firstly, the rule of law is a modest, minimalist goal, not a grand design, "applicable everywhere and to everyone, independent of political ideology or system", and therefore attractive at the end of the Cold War, when people suffered from "ideological exhaustion". Secondly, there was a renewed belief in the resilience and appropriateness of Western liberal capitalist arrangements, which seemed to have a future at a time when history was thought to have ended, and the rule of law was seen as a vital part of this success. Also, there was a "lack of ideological competition and hindrance", "no obvious alternative". Finally, the rule of law's appeal to many policy makers, diplomats and technocrats was "instrumental, not fundamental", and could arguably be put in the service of external ends - as opposed to immanent ends, the telos, in Krygier's parlance.

\footnotetext{
2 Krygier (2014).

3 Krygier (2014).
} 
All of this is persuasive and, as always with Martin, eloquent. And yet it is not entirely convincing. Put briefly, while the rule of law revival is everywhere, that does not mean that its origins are everywhere the same. This is hinted at in the third factor Krygier identifies, since there is a range of external ends which the rule of law may serve, but the suggestion that enthusiasm for the rule of law was merely a matter of instrumental convenience is not entirely accurate. This short essay is not the place to tell the long story of the rule of law revival, it just wants to give a sense of how it can be told in a slightly different manner. To this end, it briefly discusses the EU and Afghanistan.

\section{The European Union}

The European Union is an example par excellence of the rule of law revival. It is a regional organization which has increasingly preoccupied itself with building, maintaining, monitoring and strengthening the rule of law in its Member States since the late 1980s. I will briefly discuss three reasons for this, not because they are the only ones, far from it, nor because they belong to the most important ones, though I think that they do, but because they illustrate the point of this short essay: the rule of law revival was produced by factors which are highly diverse and which have been both long in the making and recent.

The first factor is the EU's constitutional identity. In a speech on The European Union and the Rule of Law in August 2015, Frans Timmermans, the first Vice-President of the Commission, who had the rule of law in his portfolio, said: "The rule of law is part of Europe's DNA, it's part of where we come from and where we need to go. It makes us what we are". ${ }^{4}$ From a political point of view this was a powerful statement vis-à-vis Orban's Hungary action had been rather less forthright. Poland's constitutional breakdown would begin later that year. From an academic point of view matters are somewhat less straightforward.

For it is unclear whether the European Community was always exclusively meant for states which respect the rule of law, as the metaphor of the DNA suggests. ${ }^{5}$ The Treaty of Rome, which was concluded in 1957 by Germany, Italy, France, Belgium, Luxembourg and the Netherlands, is foggy on this. The only hint is in the Preamble, which declares that the Six aim to pool "their resources to preserve and strengthen peace and liberty" and calls upon "the other peoples of Europe who share their ideal to join in their efforts" - but does not elaborate whether liberty should be understood as democracy and the rule of law or as the free movement of goods, services and persons. Yet in the 1960s the Community was forced to show its colours. In 1962 the two right-wing dictatorships which had survived the Second World War, Franco's Spain and Salazar's Portugal, applied for an association agreement with a view to membership. The Community refused. And in 1967 Greece, which had concluded such an association agreement with a view to membership in 1961, descended into

\footnotetext{
4 Timmermans (2015).

5 Janse (2018).
} 
a dictatorship after a military coup, thereby presenting the Community with its first ever case of what is nowadays called backsliding - albeit of an associate instead of a member, and although the means used was military force instead of the quasilegal 'reforms' which are currently en vogue in Hungary, Poland and elsewhere, as is explained in essays by Rosalind Dixon, Marcin Matczak and Kim Lane Scheppele in this Special Issue. In response, the Community froze the agreement and also imposed financial sanctions -interestingly, in view of a recent legislative proposal in the EU to sanction backsliding financially. So in the 1960s it became clear that the Community did not regard the constitutional system of its (prospective) members as an internal matter, but as a matter which directly concerned the Community, and which had consequences. In 1973 the heads of state and government of the Community, which by that time had acquired three new members, including the UK, issued a formal statement on European identity in which they unequivocally stated that respect for "the principles of representative democracy, of the rule of law and social justice" is a condition for membership.

So although it may be an exaggeration that the expectation that Member States respect the rule of law is in the EU's DNA, it is not much of an overstatement. And the fact that this expectation was first articulated in response to Mediterranean affairs discredits a commonly held view that the EU's rule of law agenda is and was all about the fear of post-communist countries in Central and Eastern Europe. But while such fears were not the origin of the EU's interest in the rule of law in its Member States, they did take that interest to the next level. In 1993 the European Council, during a summit in Copenhagen, agreed that "...the countries in Central and Eastern Europe that so desire shall become members of the European Union", provided that they were able to meet the political criterion of having "....achieved stability of institutions guaranteeing democracy, the rule of law, human rights and respect for and protection of minorities...". The European Commission was tasked to prepare post-communist countries for membership. To fulfil this task the Commission developed a method of frequently assessing the quality of the legal system in the countries concerned; of advising, financing and assisting in reforms; and of monitoring progress. ${ }^{6}$ This methodology of Member State building, to borrow the expression of Gerald Knaus and Marcus Cox, has been further refined after 2004, when the focus of the EU accession agenda shifted to Croatia, Montenegro and other countries in the Western Balkans. ${ }^{7}$ Nor did the Commission's supervision and interference wane after accession. Bulgaria and Romania became the subject of the socalled Cooperation and Verification Mechanism, a measure which was branded as temporary yet continues to exist 12 years after the accession of these two countries.

A third factor which explains the growth of EU interest in the rule of law in its Member States is the development of the so-called Area of Freedom, Security and Justice (AFSJ), a vast and complex field which encompasses international private law, asylum law and criminal law. During a summit in Tampere in 1999 the European Council decided to establish the AFSJ. The background was one of the most

\footnotetext{
6 Kochenov (2008).

7 Knaus and Cox (2005).
} 
important achievements of the EU, the creation of a single market: a territory without internal borders to enable the free movement of goods, services, persons and capital. The disappearance of physical borders, however, was not accompanied by the removal of the intangible borders between the legal systems of the Member States. This discrepancy between the free movement of goods, services, persons and capital on the one hand, and the territorial limits of the law of the Member States on the other hand, was bound to cause severe strains. This was especially visible in criminal matters: suspects or convicted criminals could escape prosecution, trial or sentencing by simply moving to another Member State. Of course extradition procedures were in place, but these were cumbersome and slow as well as being illequipped to keep up with the free movement of persons.

The solution which the Tampere European Council chose was the free movement of judicial decisions in a range of matters. Henceforth a legal decision in Member State A would be recognized and enforced in Member State B in rapid procedures with few formalities. Legal decisions acquired transnational effect. The most famous instrument was the European Arrest Warrant: Member States had to surrender their own citizens to another Member State if the citizen had committed a serious crime or was suspected of having committed such a crime in another Member State. This principle of mutual recognition solved problems but also created a fresh concern: could Member States really be certain that the legal systems of other Member States satisfied appropriate standards, not least the right to a fair trial, a core element -and not an extrinsic end but a legal expression of its telos- of the rule of law? The answer became known as the principle of mutual trust, well expressed by the Court of Justice of the EU in one of its recent cases: "EU law is...based on the fundamental premiss that each Member State shares with all the other Member States, and recognises that they share with it, a set of common values on which the EU is founded, as stated in Article 2 TEU (which states: The Union is founded on the values of respect for human dignity, freedom, democracy, equality, the rule of law and respect for human rights, including the rights of persons belonging to minorities). That premiss implies and justifies the existence of mutual trust between the Member States that those values will be recognised, and therefore that the law of the EU that implements them will be respected" (CJEU, Judgment of the Court of 6 March 2018, C-284/16, EU:C:2018:156, para. 34). In sum, one the reasons why the EU endeavours to monitor, strengthen and protect the rule of law in its Member States is because the functioning of the AFSJ and the single market depend on it and because the $\mathrm{EU}$ is committed to the right to a fair trial.

\section{And Now for Something Completely Different}

Now take another recent instance of rule of law promotion, the one that began after 9/11 in Afghanistan and shortly afterwards also in Iraq. Obviously, this had nothing to do with the causes of EU rule of law promotion in Central and Eastern Europe. It was primarily the result of the development of the military doctrine of counter-insurgency and counter-terrorism, as is explained in a chapter in a volume which Martin Krygier co-edited with Whit Mason in 2012: The Rule of Law in 
Afghanistan; Missing in Inaction. Its author, David J. KilCullen, an Australian academic and adviser to the US military and its NATO partners at the time, argues that "when a government is losing to an insurgency, it isn't being outfought; it's being out-governed". 8

Following two classical theorists of counter-insurgency, Robert S. Thomson and David Galula, KilCullen maintains that in conflicts between the state and non-state actors all warring parties strive to establish a system of control over the use of violence, economic activity, health care and other aspects of human security. Whoever is better at establishing such a system in the eyes of local populations, wins the conflict. KilCullen notes that, in Afghanistan, the state was not able to establish a system of control in vast areas and that the Taliban quickly filled that vacuum. For example, the Taliban established Shari' a law courts, which mainly dealt with commercial and civil disputes, and an Ombudsman system where people could complain against abuse at the hands of Taliban commanders. For this reason, it made no sense for the US and its allies to bolster the reach of a government which is "corrupt, is oppressing its people and is by virtually every measure failing them." 9 Rather, they should engage in "bottom-up, community based, civil society approaches" to state-building, including providing support for establishing courts or court-like entities which aim at the fair and rapid resolution of disputes. This explains the statement by General Petraeus and Lieutenant-General Amos, quoted in the introduction to this essay, that "Soldiers and Marines...must be able to facilitate establishing local governance and the rule of law".

\section{Conclusion}

So the rule of law revival can be explained by uncovering the reasons why international organizations and states decided to invest so much energy and money in building and strengthening the rule of law during the past few decades. This also helps to get a more realistic sense of the evolution of the rule of law revival, which should not be seen as an organism with a life cycle but rather as a series of parallel movements, some of which are at high speed (e.g. the EU) while others have lost much of their momentum (e.g. the International Criminal Court, Afghanistan and Iraq) and with yet others which hardly ever got going in the first place (e.g. the international rule of law). The rule of law revival is alive and kicking, walking on its last legs and stillborn at the same time.

And yet this account of the rule of law revival has its limits, too. Not only is it one-sided in having an eye for the supply side of rule of law promotion only. It also fails to explain why all the different rule of law movements, even if they had distinct and idiosyncratic causes, suddenly surfaced after the late 1980s. There must be cross-connections. And so we are back with the impulse behind Krygier's chapter on the origins of the rule of law revival: a global phenomenon must have global causes. There are more of these generic explanations, not only of the origins of the rule of law revival but also of its perpetuation, as Veronica Taylor's essay in this Special

\footnotetext{
${ }^{8}$ KilCullen (2012), p. 38.

9 KilCullen (2012), p. 48.
} 
Issue on the usefulness of the myth of the rule of law demonstrates. The Rule of Law after the Short Twentieth Century may not be among the best-known of Martin Krygier's articles and chapters, but it has certainly put the spotlight on a complex and fascinating puzzle for rule of law scholarship.

Open Access This article is distributed under the terms of the Creative Commons Attribution 4.0 International License (http://creativecommons.org/licenses/by/4.0/), which permits unrestricted use, distribution, and reproduction in any medium, provided you give appropriate credit to the original author(s) and the source, provide a link to the Creative Commons license, and indicate if changes were made.

\section{References}

Carothers T (1998) The rule of law revival. Foreign Aff 77:95-106

Janse R (2018) The evolution of the political criteria for accession to the European Community, 19571973. Eur Law J 24(1):57-76

KilCullen D (2012) Deiokes and the Taliban; local governance, bottom-up state formation and the rule of law in counter-insurgency. In: Mason W, Krygier M (eds) The rule of law in Afghanistan: missing in inaction. Cambridge University Press, Cambridge, pp 35-50

Knaus G, Cox M (2005) The Helsinki Moment in Southeastern Europe. J Democr 16(1):39-53

Kochenov D (2008) EU enlargement and the failure of conditionality: pre-accession conditionality in the fields of democracy and the rule of law. Kluwer Law International, The Hague

Krygier M (2014) The rule of law after the short twentieth century; launching a global career. In: Nobles R, Schiff D (eds) Law, society and community: essays in honour of Roger Cotterrell. Ashgate, London, pp 327-346

Timmermans F (2015) The European Union and the Rule of Law, keynote speech at conference on the rule of law, Tilburg University. https://ec.europa.eu/commission/commissioners/2014-2019/timme rmans/announcements/european-union-and-rule-law-keynote-speech-conference-rule-law-tilburguniversity-31-august-2015_en. Accessed 01 Oct 2019

United States Army (2006) Army Field Manual 3-24: Counterinsurgency, FM 3-24/MCWP 3-33.5, Appendix D, D-38

Zoellick RL (2008) Fragile states: securing development. Surviv Glob Politics Strategy 50(6):67-84

Publisher's Note Springer Nature remains neutral with regard to jurisdictional claims in published maps and institutional affiliations. 